\title{
A SUGGESTION FOR AN INFORMATION DEVELOPMENT TOOL FOR THE SELECTION OF HOUSING FURNITURE IN THE TURKISH FURNITURE INDUSTRY: AN INVENTORY OF FURNITURE \\ UNA SUGERENCIA DE HERRAMIENTA DE MEJORA DE INFORMACIÓN EN LA ELECCIÓN DE MOBILIARIO RESIDENCIAL EN LA INDUSTRIA DEL MUEBLE TURCA: UN INVENTARIO DE MUEBLES
}

Selin Ust*

Kadir Has University Istambul

\begin{abstract}
In consideration of the fact that residential interior necessitates an intense planning and design, selection of right furniture for residences gains importance. When the furniture buying process in Turkey is examined, it is known that users have difficulties in making the "right" selection among existing furniture alternatives.

Within the scope of the current study, a "furniture inventory sheet" is suggested as a tool for developing information for the furniture industry. It is thought that it can be possible for users to make a more effective choice with less risk among existing furniture items with the help of such an "inventory sheet".

Keywords: furniture, interior space, residential space, Turkey.

\section{Resumen.}

Dado que el diseño residencial de interiores, al constar de numerosas funciones, requiere de una profunda programación y diseño de soluciones, la elección del mobiliario apropiado juega un papel importante en espacios residenciales. Cuando se examina el proceso de adquisición del mobiliario en Turquía, es conocido que los usuarios tienen dificultades para hacer la elección "correcta" entre las alternativas de mueble existentes.

A través de este estudio, se propone una hoja de inventario de muebles como herramienta para la mejora de la información en el sector del mueble. Es sabido que es posible para los usuarios hacer una elección más efectiva con menos riesgo entre los elementos de mobiliario existente con la ayuda de esta suerte de "hoja de inventario".
\end{abstract}

Palabras clave: Mueble, interiorismo, espacio residencial, Turquía.

*E-mail: selintu@gmail.com 


\section{Introduction}

A dwelling carries economic, aesthetic and symbolic values as a tool of expression through which families can reflect their own identities to their society. In this context, "housing" does not merely refer to the space where a person lives in. A house is a person's home; a shelter in her/his daily life; a place which plays the most fundamental role in shaping her/his being and personality; and a protector of the valuable objects, items and memories ${ }^{1}$. While selecting furniture for their own residence, people gravitate towards the products that reflects their personality, culture, lifestyle and experience. Furniture, which is placed in a space for meeting various needs of actions, is a key element for space organization. Furniture intermediates between a place and its users, establishes a bridge between an interior and an individual in terms of form and scale, and makes a place usable by contributing comfort and utility to indoor activities ${ }^{2}$. In consideration of the fact that residential space necessitates an intense planning and design, selection of right furniture for residences gains importance.

Nevertheless, it is not easy for users to make the "right" selection among existing furniture alternatives. Furniture selection often takes place through an evaluation made among various furniture items being produced and marketed in a certain time period. To address the problem of furniture buying for their place of residence, users have to make a selection among large, medium or small scale furniture manufacturers; international furniture markets or construction markets.

\section{Turkish Furniture Industry}

The furniture industry in Turkey consists of workshop type businesses using mostly traditional methods. However the number of medium and large scale businesses has increased in last 20 years $^{3}$. Since standardisation and mass production began, the 1970 s is very important for Turkish furniture industry. Durmuş ${ }^{4}$ attributes this situation to the fact that the changes in the social structure of the nation has been transforming the traditional structure and resulting in an increase of the preference for modular furniture. Another reason for the spread of standardisation in Turkey is self-awareness of domestic manufacturers in order to be able to compete with the increasing number of foreign competitors. For the Turkish furniture industry, production with certain standards becomes compulsory in order to prove itself on a global scale and to survive. As the industry develops, features sought in products steadily increase and it becomes compulsory to produce products based on those features. Attracting attention to the fact that an environment of competition was created with the adoption of a free market economy from the beginning of the $1980 \mathrm{~s}$, Durmuş 5 argues that this environment of competition which formed for Turkish manufacturers increased the importance ascribed to the concept of design. 
As Turkish furniture began to find a place in the global market, the nation faced the necessity of high-quality manufacturing and recognised the need of renewal. International expansion has led to many huge changes in the furniture industry, ensuring the introduction of new products in social life and various important products have enabled consumers to become more conscious ${ }^{6}$.

The social, political, economic and technological changes experienced in the 1980s resulted in a variety of notions which influenced the industry. These events, starting from the 1980s enabled the formation of the furniture industry which was further shaped by the influence of globalisation in the 1990s. Increased housing constructions and typologies ensured that the trends in the furniture industry were based on housing. The need of self-renewal that emerged with international expansion in the Turkish furniture industry revealed the need for designing unique products and rendered its adoption an imperative. Furniture designs beginning to be shaped especially with the concept of unique design in our day have begun to enliven the industry in a sense ${ }^{7}$.

In the 1990s, Turkish furniture became able to compete in global markets. Its ability to survive in this difficult market led to the necessity of producing products with unique designs in global standards ${ }^{8}$. The Turkish furniture industry which started with small workshops has reached an industry level manufacturing.

The domestic market addressed by the furniture industry has created an increasingly high demand. The need for housing rapidly increases in parallel to the population, welfare, urban migration and socio-economic developments. The demand for furniture is kept alive by the need for using spaces that get smaller and smaller as a result of the conceptual changes in the housing industry requiring more flexibly and functionally. On the other hand, the changes occurring in the family structure as a natural result of these developments have increased the demand for furniture even more. In turn, this situation caused such shopping centres focused exclusively on furniture such as IKEA, Tepe and Habitat, looking to take their share from this boom, to want to enter this industry. Classical understanding of furniture had to give way to furniture markets.

Increasing awareness of consumers and the rapid development of tastes and expectations made a change inescapable in the line of furniture. As consumers advanced, features sought in furniture products also increased. It became necessary for manufacturers to produce products based on these criteria ${ }^{9}$.

\section{The current furniture selection process}

A user who wants to buy furniture for his/her house begins to collect information and identify alternatives within the framework of the needs they determine. They limit alternatives based on certain assessment criteria to make a selection. 
It is necessary to examine the process of making a buying decision in order to understand how users perform the actions of product selection, liking and buying. In the buying process, buying is described as solving a problem solving, and a user passes through five stages of the solution which are problem recognition, information research, identifying alternatives, assessing alternatives and making a selection. After a user determines their need, they begin to collect information and seek alternatives regarding the product which will meet the need. In this process, the goal is to make the most correct selection from among the alternatives ${ }^{10}$.

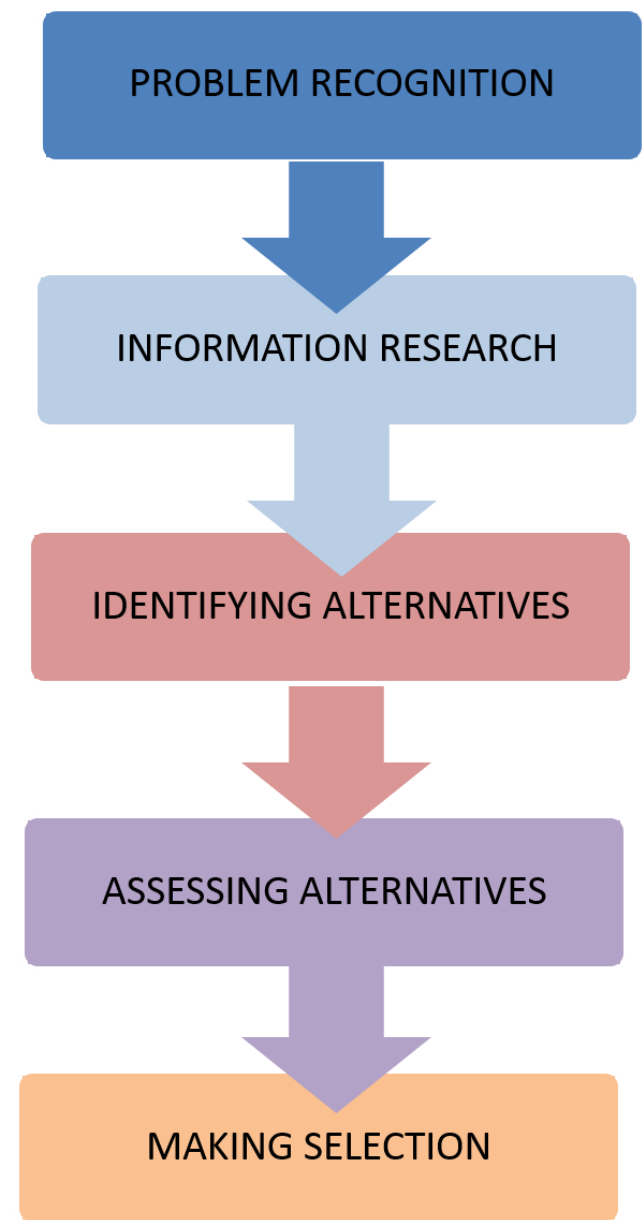

Fig. 1. Stages of the decision-making process (Kotler\&Armstrong, 1998).

The target profile which is described as a "user" by the design discipline is named a "consumer" by the marketing discipline within the context of the relationship established with a product in the buying process. Consumer buying behavior is "the study of individuals, groups or organizations and the processes they use to select, secure, use and dispose of products, services, experiences or ideas to satisfy needs and the impacts that these processes have on the consumer and society"11. According to consumer behaviour is not about only buying things; but also the study of how having (or not having) things affects our lives and how 
possessions influence the way we feel about ourselves and each other-our state of being.

Companies make researches on buying decisions of customers to answer questions about what consumers buy, where they buy, how and how much they buy, when they buy, and why they buy (Kotler and Armstrong, 1998). Therefore, it is necessary to group the variables which influence the buying process in order to be able to explain consumer behaviours.

- Demographic factors

- Cultural factors

- Social factors

- Psychological factors

- Situational factors

\section{Demographic factors}

Age, gender, occupation, educational status, income status and therefore the lifestyle of a consumer lead to a diversification of his/her needs and desires and a change in his/her buying decisions.

The scope of the study conducted by Burdurlu et al.,12 examined the relationship between the demographic characteristics of users and their furniture preferences in Turkey. The results show that the characteristics which the consumers within the age group of 25 to 35 attribute the highest importance to is price and that the criterion which is cared for most by those in all other age groups is furniture quality. According to Burdurlu et al., the reason for this is that users below 35 years of age are new in business life and therefore their salaries and thus their purchasing power are lower. Also analysing the place of gender in furniture preferences, it is emphasised in the same study that gender of consumers leads to certain differences in the products needed and buying behaviours. As the educational status of users are related to their life standards or expectations, it influences their buying preferences significantly. As the educational level increases, the price based buying decisions give way to quality based buying decisions ${ }^{13}$.

\section{Sociocultural Factors}

Family structure and life cycle and the various roles of family members influence their preferences. Levitt ${ }^{14}$ states that the number of individuals living in a household influences their buying preferences and argues that the interior of a housing should be differentiated according to the related family structure and family life cycle. For example, in order to spend an enjoyable time together, having conversations and eating in their houses, families with children need a common area, a balcony, separate rooms for children, a service area for washing, drying and ironing clothes, and a warehouse where household items not 
frequently used can be stored. An individual who lives alone, on the other hand, prefers a living area with an open plan that contains all the activities of seating, cooking and eating ${ }^{15}$. Each member in a family has a role (giving ideas, influencing, decision taking, actually buying, using) and the process of consumption operates accordingly.

When a consumer makes a buying decision, they might want support and opinion from the person, family, group or organisation / reference group that they trust ${ }^{16}$.

There is an indirect relationship between the taste of a consumer and their lifestyle. While taste is a reflection of a consumer's lifestyle, lifestyle is the main factor which determines taste. Lifestyle refers to the profile of consumer individuals and groups about how they live, what and how they consume, their expenditure and daily lives ${ }^{17}$. In a society, there are many social groups reflecting various lifestyles. For each lifestyle, there is a special element of taste which is not present in other lifestyles. According to Englis and Solomon, differences in consumption patterns are created by social groups with different lifestyles (1995). According to this view, an individual's consumption preferences provide clues about the social group which they belong to. Status is described as a rating of individuals in a hierarchy based on certain criteria. As the members of a social class display similar behaviours, this factor can result in market segmentation. Variables examined according to the index of status characteristics are collected in 6 groups: Occupation, income level, income source, education, type of housing, and living environment structure ${ }^{18}$.

\section{Psychological Factors}

The psychological factors that come from inside of an individual, which are consumer perception, motivation and attitude can also influence consumer buying behavior ${ }^{19}$.

In the alternatives identification stage of the buying process, the perception filter steps in. In perception, previous experiences of a person have a great importance and therefore perception is a subjective process the extent of which depends on the needs of a person, intensity of those needs, priorities of those needs and expectations of the related person ${ }^{20}$. For example, two people who go out to choose furniture might perceive the same product differently. So, one of them might like and want to buy that product while the other does not.

Motivation is the force which determines priorities depending on the purpose of buying and which triggers the buying behaviour by directing a consumer to buying ${ }^{21}$.

Beside motivation and perception, consumer attitude also acts as a crucial factor that influence people purchasing decision. Attitude consists of three components, which are cognitive (knowledge and belief), affective (feeling), and behavioral (action) ${ }^{22}$. According to Tokol, attitudes and beliefs are the thoughts, values and habits which are created by a person as a result of another person 
they met before, an event or a place that they experienced as well as personal characteristics like taste, appearance and superiority. "It is not easy to change a habit acquired. An individual's positive or negative feelings or tendencies regarding an idea, a product or a symbol are an acquired habit and it is difficult to change it"23. In the furniture buying process as well, a person would prefer again the shop and the product which they previously tried and liked while they will be prejudiced against certain products and shops. For example, even if customers find an exact same product at a cheaper price in another construction market, they feel a concern about whether to buy that product from that shop ${ }^{24}$.

\section{Situational Factors}

It is possible to name the third variable that influences consumer behaviours as situational factors. The situational factors which influence the buying behaviour of individuals can be collected under the headings of physical environment, social environment, time, reason for buying, and emotional and financial status.

Physical environment is the factor which is related to the environment where consumers display their buying behaviours. Dimensions of the physical environment, such as decor, smells and even temperature can significantly influence the buying decisions of consumers ${ }^{25}$. As a result of a study that was carried out in France, it was determined that strawberry and vanilla smells lead people to the buying behaviour. Interviews were made with specialists of the furniture industry on shops, markets and the importance of spatial elements in their marketing strategies. It was stated that the indoor atmosphere which is created by such elements as colour, light, temperature, sound and smell, and its spatial organisation are elements which can make consumers loyal to a shop. In addition to physical cues, many of a consumer's purchase decisions are significantly affected by the social environment. The presence or absence of coconsumers- the other patrons in a setting is also a determinant attribute in a buying decision ${ }^{26}$. Customers prefer the shops where they feel safe and where they can walk around comfortably. According to Kutlu, one of the most important reasons for why customers prefer construction markets for buying furniture is that a construction market is a comfortable and low-priced shopping environment where they are not followed by shop employees. It is emphasised that construction markets do not attach such tags on furniture groups as "please don't seat on this" or "please don't touch" but that, on the contrary, they adopt a principle which is based on "experiencing"27.

The time factor is also influential on buying behaviours of consumers. When the product to be bought is furniture, customers go to shopping the most when schools are opened, in February semester holidays and in wedding preparations depending on their needs and thus the most intense season of furniture shopping occurs between the months of September and March ${ }^{28}$. 
The reason for which an individual buys a product and their emotional and financial status during the shopping can also influence the process of alternative identification, assessment and decision taking ${ }^{29}$.

\section{An Information Developing Tool in the Selection of Housing Furniture}

It becomes gradually more difficult for users to make furniture selections from among innumerable businesses, companies and markets. Within this complex structure, it will be right to address furniture without breaking it off from spatial context and in fact with its characteristic of a transition between an indoor space and a user.

With the help of the model suggested, it is aimed to make it easier for a user to make a right selection from among furniture items belonging to different companies and help them place such items into their housing more effectively.

A relational model is envisaged which a user can use for making a healthy comparison among various existing furniture items with less risk fir an erroneous selection. A housing user who begins to perform market research for buying furniture can easily identify alternatives with the help of the "information developing tool" in the suggested model and assess which of the identified alternatives to choose from within the context of the identified criteria ${ }^{30}$.

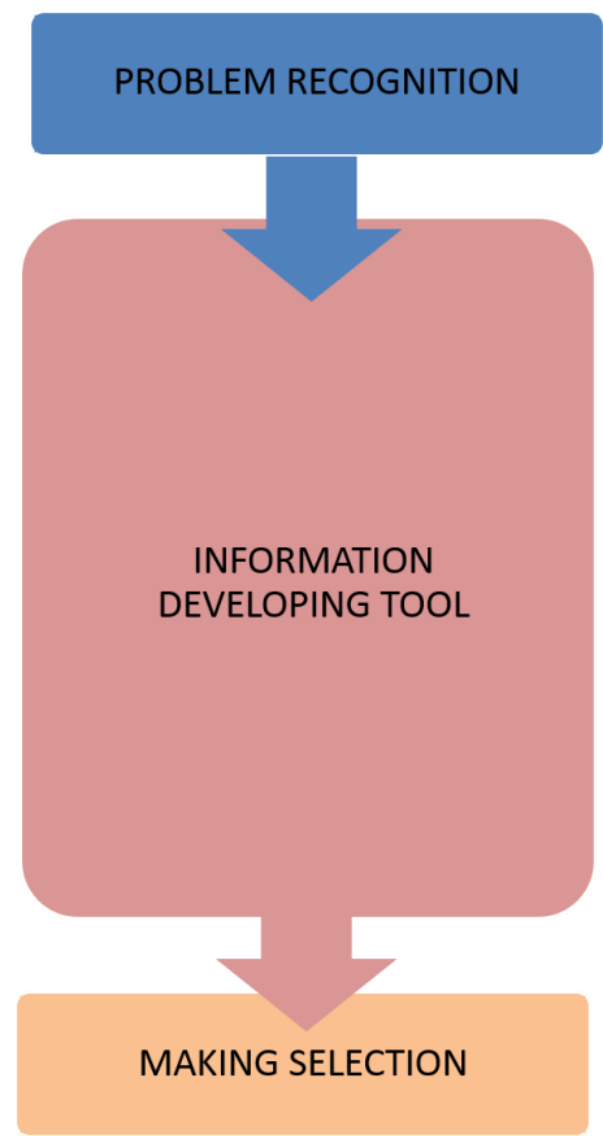

Fig. 2. Suggested model (Üst, 2015). 
Within the scope of the study, it is suggested to create a furniture inventory sheet as the tool of information development. Inventory sheets are tables providing users with comprehensive information on products. The sheets were prepared with exhaustive details in order to ensure that users can establish the accessory-space relationship with minimum errors. Following a product visual and name and the company to which the product belongs, information is provided about technical characteristics such as the type of product according to its purpose of use, material production method, dimensions, colour, tissue, unit weight, geometry and endurance, application characteristics such as scalability and storage and also economic characteristics. Information on quality certificate, service and warranty conditions is also provided in the sheets.

The aim is to ensure that users make fewer errors when they select furniture for an existing space by utilising the comparative furniture inventory sheets and thus a more effective furniture layout in housing indoors.

It is planned to bring sheets together and transform them into a catalogue system for the mass production housing furniture industry. The aim is to ensure that users make less errors when they select furniture for an existing space by utilising the comparative furniture inventory sheets and thus a more effective furniture layout in housing indoors.

What is ideal for the catalogue is open systems whereby repeating components form a harmonious whole. Open system is a method of application created by utilising catalogue components. Especially in those components which contain frequent repetitions, companies design products based on pre-set rules and, with a more technical term, conventions, and promote those products in a catalogue. A component market, which forms when all the company catalogues are combined as a whole, creates the open system general catalogue.

The approach of creating products by partially utilising catalogue components as a type of application which applies to the building construction industry. Catalogue components which are partially used in a construction include bathroom equipment, heaters, radiators, doors and windows, dividing panels, deck girders, and similar items.

Although many industrialised building systems have been developed and applied from past to the present, these systems have been mostly criticised. The primary item of criticism is "typified solutions" provided by systems by their nature. The approach recommended for the furniture industry is to provide an environment of user-furniture relationship which repeats in the component level but which can respond to the diversity of user desires and needs ${ }^{31}$. 


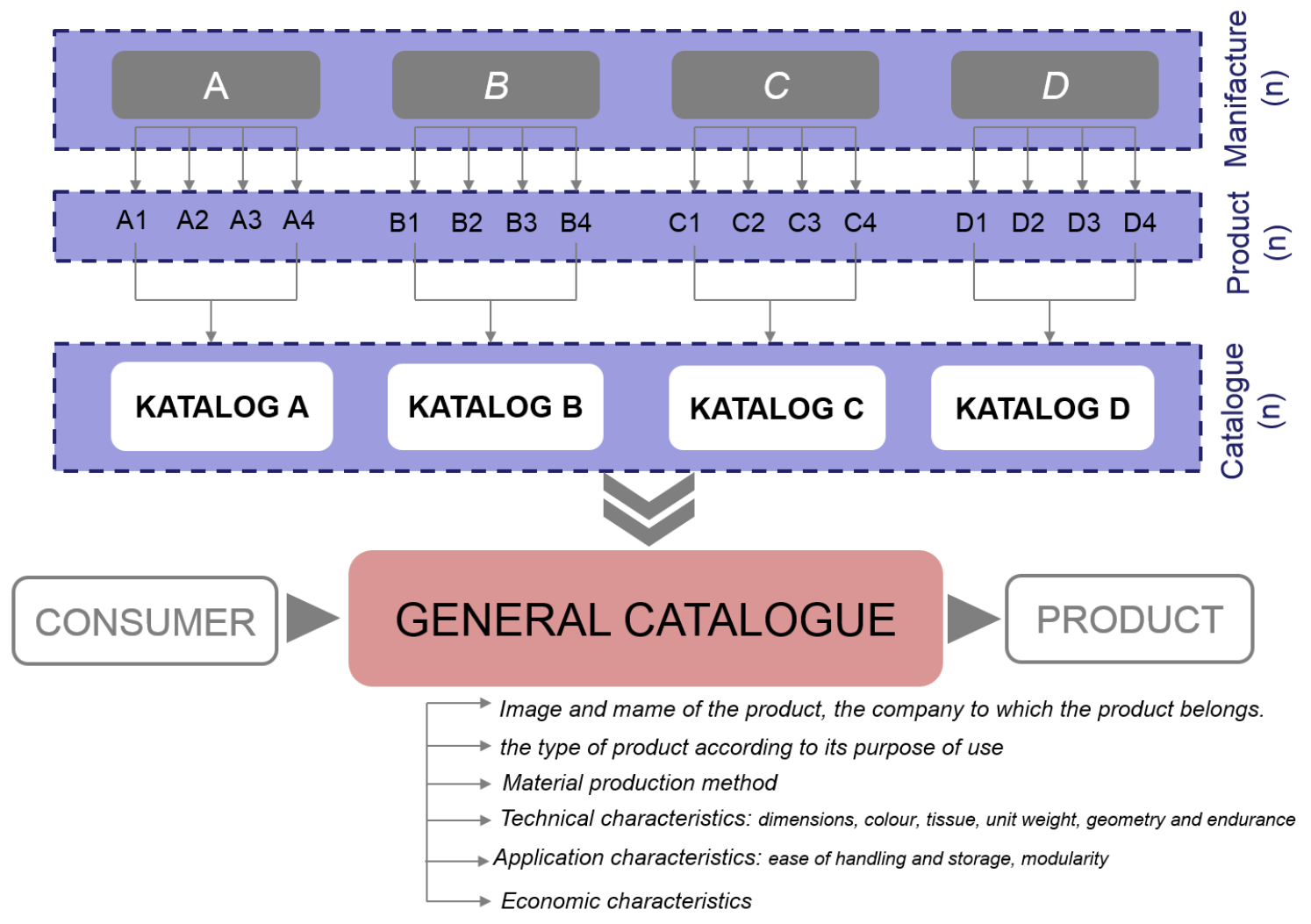

Fig. 3. Consumer-product flow chart (Üst, 2015).

The most important point in this approach is the fact that the "conformance rules", that is, "conventions" which all the furniture manufacturers and designers will comply with have already been provided. The philosophy of open system, which is based on universality, targets to create an international market with agreed rules. In his book titled Open Systems in an Industrialised Building (original title, Endüstrileşmiş Binada Açık Sistemler), Hasan Şener analysed "conformity rules" in five categories ${ }^{32}$.

- General conventions: They aim to ensure the geometric conformity of components with each other. According to general conventions, the concepts of modular coordination, dimensional coordination, changeability, adaptability and flexibility gain importance.

- Special conventions: These are rules relating to joints.

- Quality conventions and component catalogues: These are rules relating to determining various physical characteristics of components.

- Conventions relating to organisation of markets: These are rules relating to the postproduction process.

- Conventions relating to responsibilities, warranties and insurances.

The study suggests that mass production furniture and an industrialised component can be designed and manufactured based on certain conventions and take place in an open system catalogue and that the limits of mass manufactured furniture can be pushed by creating different compositions containing 
harmonious components and special combination details in company level. Mass production by harmonious components and special combination details will bring new points of view of furniture design.

\section{Results and Suggestions}

It is important in terms of ensuring the sense of belonging that the furniture selection that a user makes for their own dwelling place reflects their personal preferences. The contribution that the furniture catalogue aims to make is to guide a user to enable them to establish the space-furniture relationship with minimum errors with the help of the criteria given in the catalogue. Thanks to these catalogues, users will be able to comparatively select products for a space.

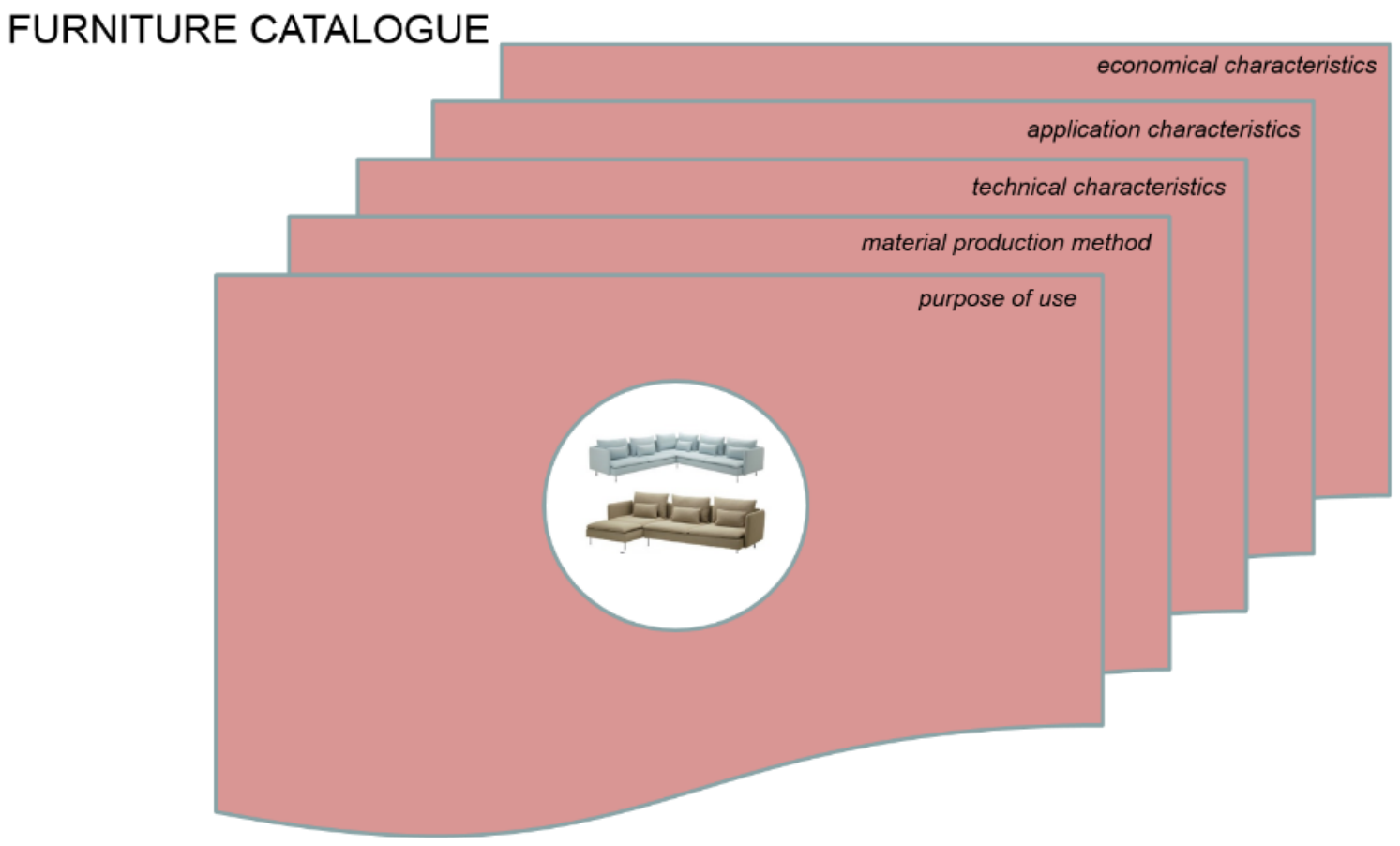

Fig. 4. Furniture catalogue.

The furniture catalogue to which the furniture manufacturing companies operating in Turkey contribute components independently from one another is likely to help users in the stage of product selection and decrease erroneous selections.

The fact that machinery stepped in with industrial revolution caused space dependent furniture to give way to digital production. An effective placement of furniture manufactured independently of space has gained importance. At this point, furniture companies' provision of catalogues to support users can be a step for preventing the basic errors that users make in product selection. It will be 
especially beneficial to guide a user who is conditioned to buy all the pieces of dining room, bedroom or living room furniture as a set based on technical characteristics like product dimensions, colour, tissue, unit weight, geometry and endurance; application characteristics such as scalability and storage; and economic characteristics.

\section{NOTES}

${ }^{1}$ PINK, Sarah, Home Truths: Gender, Domestic Objects and Everyday Life, Oxford, Berg Publishers, 2004 MILLER, Daniel, Home possessions: Material Culture Behind Closed Doors, Oxford, Berg Publishers, 2001.

${ }^{2}$ CHING, Francis, Architecture: Form, space, order, John Wiley\&Sons, 2007.

${ }^{3}$ KADES, Cenk, Adana Ticaret Odası Mobilya Sektör Raporu 2012, Adana, Adana Ticaret Odası, 2012.

${ }^{4}$ Durmuş, Serpil, Türkiye'de Modern Mobilyanın Gelişimi, Master's thesis, İstanbul, Marmara University, 2005.

${ }^{5}$ Ibidem.

${ }^{6}$ Ibidem.

${ }^{7}$ Ibídem, ÇALIŞKAN, Cemal Irfan, Globalleşme Sürecindeki Dünyada, Türkiye Mobilya Tasarım Anlayıışındaki Değişmeler, Master's thesis, Istanbul, Marmara University, 2005.

${ }^{8}$ ÇALIŞKAN, Cemal Irfan, Globalleşme Sürecindeki Dünyada, Türkiye Mobilya Tasarım Anlaylşındaki Değişmeler, Master's thesis, Istanbul, Marmara University, 2005.

${ }^{9}$ DURMUŞ, Serpil, Türkiye'de Modern Mobilyanın Gelişimi, Master’s thesis, İstanbul, Marmara University, 2005 .

${ }^{10}$ KOTLER, Philip \& ARMSTRONG, Gary, Principles of marketing, Englewood Cliffs, N.J., Prentice Hall, 1998.

${ }^{11}$ HAWKINS, Delbert \& MOTHERSBAUGH, David, Consumer Behavior Building Marketing Strategy, Vol. XII, McGraw-Hill, 2013, p. 6.

${ }^{12}$ BURDURLU, Erol, İLÇE Abdullah Cemil, CİRİTOĞLU Hasan Hüseyin, "Mobilya Ürün Özellikleri ile Tüketicilerin Tercih Öncelikleri”, Hacettepe Sosyolojik Araştırmalar E-Dergisi, 2004.

${ }^{13}$ BURDURLU, Erol, İLÇE Abdullah Cemil, CİRITOĞLU Hasan Hüseyin, "Mobilya Ürün Özellikleri ile Tüketicilerin Tercih Öncelikleri”, Hacettepe Sosyolojik Araşttrmalar E-Dergisi, 2004.

${ }^{14}$ LEVITT, David, The housing design handbook: A guide to good practice, London, Routledge, 2010.

${ }^{15}$ Ibidem.

${ }^{16}$ BURSALI, A., 12-18 Yaş Arasındaki Çocukların Aile Satın Alma Kararına Etkileri, Yüksek Lisans Tezi. Sakarya Üniversitesi, Sakarya, 2008.

${ }^{17}$ BİLGIN, Nuri, Eşya ve İnsan, Ankara, Gündoğan Yayınları, 1991.

${ }^{18}$ AKYÜZ, İlker, Mobilya Satın Almada Tüketici Davranışlarını Etkileyen Psikolojik, Sosyo-Psikolojik ve Sosyo Kültürel Faktörlerin Incelenmesi, $\mathrm{PhD}$ thesis, Trabzon, Karadeniz Technical University, 2006.

${ }^{19}$ SCHIFFMAN, Leon \& WISENBLIT, Joseph, Consumer Behavior, Vol. XI, England, Pearson Education Limited, 2015.

${ }^{20}$ ODABAŞI, Yavuz \& BARIŞ, Gülfidan, Tüketici Davranışl, Istanbul, MediaCat Akademi, Esen Ofset, 2002.

${ }^{21}$ İSLAMOĞLU, Hamdi, Tüketici Davranışları, İstanbul, Beta Basım A.Ş., 2003.

${ }^{22}$ HAWKINS, Delbert \& MOTHERSBAUGH, David, Consumer Behavior Building Marketing Strategy, Vol. XII, McGraw-Hill, 2013.

${ }^{23}$ TOKOL, Tuncer, Pazarlama Yönetimi (10th edition), Bursa, Uludağ Üniversitesi Basımevi, 2007.

${ }^{24}$ KUTLU, Tayfun, Marketing and Store Planning Director of Koçtaş, Personal Interview, 2012.

${ }^{25}$ SOLOMON, Micheal, BAMOSSY, Gary, ASKEGAARD, Soren, HOGG, Margaret, Consumer BehaviourEuropean Perspective, Pearson Education Limited, 2006.

${ }^{26}$ Ibidem.

${ }^{27}$ KUTLU, Tayfun, Marketing and Store Planning Director of Koçtaş, Personal Interview, 2012. 
${ }^{28}$ KUTLU, Tayfun, Marketing and Store Planning Director of Koçtaş, Personal Interview, 2012, ÖZMERT, Mustafa, Brand Marketing Chief of Istikbal, Personal Interview, 2012.

${ }^{29}$ ODABAŞI, Yavuz, BARIŞ, Gülfidan, Tüketici Davranışı, Istanbul, MediaCat Akademi, Esen Ofset, 2002.

30 ÜST, Selin, “Toplu Konutlarda Yaşama Mekanları İle Seri Üretim Mobilya Etkileşimi Üzerine Bir Araştırma”, PHD thesis, Istanbul, İstanbul Techical University, 2015.

${ }^{31}$ Ibidem.

32 ŞENER, Hasan, Endüstrileşmiş Binada Açık Sistemler, İstanbul, İTÜ Mimarlık Fakültesi Baskı Atölyesi, 1990.

Fecha de recepción: 19 de abril de 2016

Fecha de revisión: 21 de julio de 2016

Fecha de aceptación: 28 de julio de 2016 